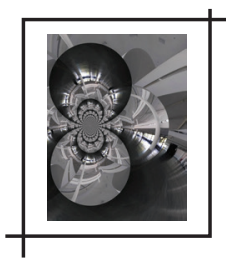

\title{
CURADORIA, CORPO E PERCEPÇÃO NA 33ª BIENAL DE SÃO PAULO: UMA CARTOGRAFIA SOMAESTÉTICA
}

\author{
Lucia Leão* \\ Luma Oliveira**
}

Resumo: Neste artigo, as relações entre processos de criação em curadoria, experiência estética e percepção do corpo são exploradas. Projetos de curadoria de grandes exposições de arte, como a Bienal de São Paulo e a Documenta de Kassel, buscam, em suas propostas, estimular experiências estéticas transformadoras em vários sentidos. Nesse contexto, nosso objetivo é discutir como o projeto curatorial da 33a Bienal de São Paulo (2018), com coordenação geral de Gabriel Pérez-Barreiro, problematiza a percepção do corpo tanto na relação do visitante com seu corpo individual como em rede com o corpo das obras e do espaço expositivo. Nosso argumento é que Pérez-Barreiro, em sua curadoria, empreende uma experiência que potencializa diferentes graus de consciência corporal. 0 artigo propõe reflexões sobre o conceito de somaestética (SHUSTERMAN, 2008) e adota a cartografia como método (LEÃO, 2011).

Palavras-chave: Processos de criação em curadoria. Bienal de São Paulo. Experiência estética. Percepção do corpo. Cartografia.

\section{INTRODUÇÃO: PENSANDO O CORPO E A SOMAESTÉTICA}

Como a questão do corpo é trabalhada no projeto curatorial da 33a Bienal de São Paulo (2018)? 0 objetivo do presente artigo é traçar uma cartografia do corpo, tanto do corpo vivido pelos visitantes como nas relações com as obras e com o espaço expositivo, a partir da perspectiva da somaestética. Nosso argumento é que, em suas escolhas criativas e na montagem expositiva, a Bienal é potencialmente capaz de provocar percepções transformadoras do corpo vivo e da própria ideia de consciência do corpo.

A consciência do corpo é uma ideia de múltiplos significados. Richard Shusterman (2008), em seu livro sobre a somaestética, propõe as bases para um projeto de caráter teórico e

\footnotetext{
* Pós-Doutora em Artes pela Universidade Estadual de Campinas (Unicamp) e Doutora em Comunicação e Semiótica pela Pontifícia Universidade Católica de São Paulo (PUC-SP). Professora do Programa de Pós-Graduação em Comunicação e Semiótica da PUC-SP. Autora do livro 0 labirinto da hipermídia e 0 chip e o caleidoscópio.E-mail: lucleao@pucsp.br.

** Doutoranda em Comunicação e Semiótica na Pontifícia Universidade Católica de São Paulo (PUC/SP). Mestra em Estudos de Linguagem pela Universidade Federal de Mato Grosso (UFMG). Graduada em Artes Visuais pela UFMS).
} 
prático cujo objetivo é estimular o desenvolvimento de uma consciência corporal ampliada e, com isso, expandir as capacidades intelectuais, performativas e de prazer. Segundo o filósofo, a somaestética é um estudo crítico de como nós vivemos a experiência do corpo, como utilizamos esse corpo vivo (soma). Shusterman (2008), dando continuidade à sua pesquisa sobre "Viver a arte" e ao percurso reflexivo traçado por John Dewey sobre "arte como experiência", defende que o corpo é o lugar da apreciação estético-sensorial e da autoformação criativa. Em seu argumento, Shusterman (2008) compreende corpo, mente e cultura como intimamente entrelaçados e mutuamente dependentes.

Para o filósofo, embora muitos autores tenham se dedicado a refletir sobre o corpo, a maioria dessas reflexões discute apenas como o corpo se apresenta para os outros, em termos de normas sociais, convenções e modelos. Em seu estudo crítico sobre o estatuto do corpo no pensamento filosófico, Shusterman (2008) retoma Foucault, Pierre Hadot, Merleau-Ponty, Simone de Beauvoir, Wittgenstein, William James, entre outros. Buscando ir além da visão dualista, Shusterman (2008) celebra a tríade corpo/mente/cultura como fenômeno complexo. Assim, para ele, o projeto da somaestética está diretamente ligado à ideia de percepção e consciência.

No diagnóstico que apresenta sobre a condição do homem na cultura contemporânea, Shusterman (2008) elenca distúrbios como estresse, superestimulação, excesso de cobranças, cansaço e problemas de atenção. É possível traçar paralelos entre o diagnóstico de Shusterman e o pensamento de Han (2017), filósofo que dá continuidade aos estudos de Foucault sobre biopolítica e afirma que estamos vivendo uma cultura fundada em dispositivos de psicopoder. Nessa cultura, passamos a nos considerar empreendedores de nós mesmos, valorizamos a produtividade e assumimos uma postura de eternos devedores. Para conseguirmos sempre superar as metas que estabelecemos para nós mesmos, estamos sempre nos cobrando resultados, exigindo comportamentos altamente competentes, o que nos leva a transtornos mentais como depressão, ansiedade e fadiga crônica.

Em vários sentidos, o presente artigo está em sintonia com pesquisas que desenvolvemos anteriormente sobre o tema do corpo e que se desdobraram em três caminhos: 1. a percepção do corpo e o conceito de labirinto de espelhos (LEÃO, 2005); 2. o corpo como rede (LEÃO, 2005); e 3. o projeto da performance e instalação interativa Corposcopio (LEÃO, 2006). Em todos esses trabalhos, defendemos que nosso interesse vai muito além da ideia reducionista de corpo como forma. Nossa intenção é pensar o corpo como processo vivo e multiplicidade. Assim, o conceito de corpo que adotamos envolve a ideia de corpo físico como algo em constante transformação, inextricavelmente conectado com a ideia de consciência (individual e coletiva) e em constante interação com a cultura. Naqueles estudos, dialogamos com a ideia de corpos sutis, autopoiesis e consciência corporificada (MATURANA; VARELA, 1991).

Para a presente reflexão, propomos três percepções do corpo: 1. o corpo individual em relação com as obras da Bienal; 2. o corpo individual em relação com o espaço expositivo; 3. 
o corpo individual em relação com os corpos dos outros visitantes. Assim, partindo dessa perspectiva, daremos início à nossa cartografia e às reflexões sobre como a experiência de visitar a exposição atua na percepção e na consciência do corpo.

\section{A PROPOSTA CURATORIAL}

Projetos de curadoria de grandes exposições de arte, como a Bienal de São Paulo, a Bienal de Veneza e a Documenta de Kassel, buscam, em suas propostas, estimular a emergência de experiências estéticas transformadoras (O'NEILL, 2012; OBRIST, 2014; SALLES, 2010; SMITH, 2012). Nesse contexto, o projeto curatorial da 33a edição da Bienal de São Paulo de 2018 se destaca pelo intuito de explorar as potências cognitivas da percepção a partir do estímulo das relações do espectador com as obras. Em seu discurso, o curador-geral, Gabriel Pérez-Barreiro, fala da atenção como caminho para a curadoria e propõe experiências múltiplas. A ideia está também claramente expressa na proposta de convidar sete artistas para desenvolverem curadorias. No convite, Pérez-Barreiro dá ampla autonomia para os artistas-curadores desenvolverem suas propostas, impondo apenas três condições: os artistas deverão expor as próprias obras, a exposição deve ocorrer no Pavilhão da Bienal e os gastos precisam ficar dentro do orçamento fixado (que é o mesmo para todos).

No título da mostra, Afinidades afetivas, Pérez-Barreiro interconecta duas referências: As afinidades eletivas, livro de Goethe, e Da natureza afetiva da forma na obra de arte, tese de doutorado defendida pelo crítico de arte e ativista Mário Pedrosa.

Façamos um breve preâmbulo para refletir acerca das referências escolhidas por Pérez-Barreiro. 0 romance de Goethe descreve o conflito vivido por Eduard e Charlotte, um casal aristocrático que, ao receber em casa um amigo de infância do marido e uma afilhada da esposa, veem seu casamento ameaçado quando se percebem apaixonados pelos hóspedes. Conforme o olhar de Pérez-Barreiro (2018), a relevância da obra é marcada, sobretudo, pela passagem em que um dos personagens lê um tratado científico que explica reações químicas eletivas de atração e repulsão de elementos e moléculas, traçando um paralelo com os conflitos vividos na história:

Se nossos gostos e afinidades são governados por leis que não entendemos totalmente, talvez estejamos diante de um sistema de organização que não é exclusivamente moral ou cultural ou biológico, mas um estranho amálgama dos três, no qual nossas afinidades, sejam elas conscientes ou inconscientes, nos conduzem (PÉREZ-BARREIRO, 2018, p. 1).

Ou seja, o interesse do curador está justamente na interconexão dos três campos (cultural, moral e biológico) como vetor de força na construção de afinidades. A tese de Pedrosa, por 
sua vez, irá fornecer a Pérez-Barreiro os argumentos que valorizam a participação do público na fruição da obra de arte. Em diálogo com a teoria da Gestalt, Pedrosa defende a construção do entendimento de uma obra por parte do espectador, levando em consideração um posicionamento ativo deste em relação à arte. Sobre isso, Pérez-Barreiro (2018, p. 1) afirma: "Para Pedrosa, a arte devia ser julgada essencialmente em termos de sua capacidade de criar uma relação produtiva entre a intenção do artista e a sensibilidade do espectador".

Nesse âmbito, vale destacar a importância da figura de Mário Pedrosa no campo internacional das artes. No ano de 2017, Pedrosa teve uma grande exposição dedicada às suas produções intelectuais (dos anos 1930 aos 1970). Com a curadoria do próprio Pérez-Barreiro, juntamente com Michelle Sommer, a mostra ocorreu no Museu Reina Sofía, em Madri.

Para Francisco Dalcol (2017), a exposição das obras de artistas que marcam as ideias de Pedrosa, juntamente com trechos de seus textos, foi fundamental para situar o pensamento do crítico ou, conforme a familiaridade do visitante com suas críticas, para realizar o processo inverso. Dalcol (2017), ao indicar Pedrosa como o mais importante e influente crítico de arte brasileiro do século $X X$, desenvolveu uma relevante compreensão da história da arte no Brasil, partindo de articulações entre arte e política. Segundo Dalcol (2017), a arte, para Pedrosa, é uma necessidade vital, diretamente ligada à política:

[...] ao contrário da pop art americana e inglesa, que trabalhava com imagens da mídia e da cultura de consumo, os artistas da nova figuração brasileira tinham como força o comentário de alta voltagem política, mobilizados em torno da crítica contra o autoritarismo, a repressão e a supressão das liberdades individuais. Não era uma pop art festiva e celebratória do apogeu da sociedade capitalista, mas consciente do contexto político das ditaduras que passava a tomar a América Latina com apoio e colaboração do imperialismo norte-americano.

Segundo a visão de Dalcol (2017), a relação entre arte e política, aplicada aos planos prático e teórico do desenvolvimento intelectual da arte brasileira, tem a "capacidade de revolucionar realidades, mentes e afetos", apontando para a liberdade revolucionária que Pedrosa encontra no moderno.

Voltando à reflexão sobre a proposta curatorial da 33ª Bienal, é importante enfatizar que, além dessas duas referências (Goethe e Pedrosa), Pérez-Barreiro evoca duas outras questões importantes para a cultura contemporânea. A valorização da multivocalidade (presente no convite à partilha da curadoria) e do poder da atenção (que fundamenta seus argumentos e o projeto educativo). Assim, é válido frisar que o desafio de desenhar uma curadoria descentralizada é parte fundamental na proposta de Pérez-Barreiro (2018) à medida que seu projeto respeita a liberdade dos artistas-curadores na proposição de afinidades e relações, assim como também dos visitantes, que são incitados a desvelar as próprias escolhas: 
Se pudermos pensar na arte e em suas exposições essencialmente como experiências, e não como declarações, talvez possamos imaginar uma Bienal em que os artistas, curadores e espectadores são tratados como iguais, todos capazes de construir suas próprias afinidades afetivas com a arte e com o mundo além dela.

\section{CONSIDERAÇÕES SOBRE O MÉTODO DA CARTOGRAFIA}

A cartografia como método fundamenta a perspectiva das discussões do grupo de pesquisas em Comunicação e Criação nas Mídias do Conselho Nacional de Desenvolvimento Científico e Tecnológico (CCM/CNPq)', assim como também os diversos trabalhos que orientamos. Os pressupostos desse método se encontram no pensamento de Deleuze e Guattari, em especial no conceito de rizoma, presente na obra Mil platôs. Para a dupla, a cartografia se realiza em redes, busca evidenciar relações, agenciamentos, não tem por objetivo sedimentar verdades, não tem princípio nem fim e é realizada a partir de multiplicidades e heterogeneidades (LEÃO, 2011).

Nossa proposta de método cartográfico foi sendo criada a partir de um longo trajeto que envolveu escolhas afetivas, contatos com a arte, o fazer criativo, a paixão pelos estudos da imagem e imaginários e a semiótica peirciana. Sobretudo, essa abordagem foi se transformando em contato com a prática da pesquisa, o desenvolvimento de projetos colaborativos, a liderança do grupo de pesquisas CCM, o exercício da orientação de alunos e docência. Conforme elaboramos anteriormente, a cartografia é um caminho de investigação que valoriza o pensamento em rede, sendo assim muito importante para o trabalho sob o ponto de vista das pesquisas em processos de criação. Por ser muito mais um sistema e um jogo, um dispositivo que coloca o pensamento em fluxo e estimula a imaginação, a cartografia favorece associações imprevistas, movimentos e experimentações heterogêneas. Assim, ao funcionar como uma máquina agenciadora de descoberta, acreditamos que a cartografia seja o método mais adequado para os objetivos do presente artigo que envolve escolhas afetivas e imersões em experiências somaestéticas.

\section{VISITANDO A BIENAL: UMA CARTOGRAFIA}

Visitar uma Bienal é sempre uma experiência complexa, multidimensional. É uma atividade que envolve planejamento, estimulando nossos corpos em várias camadas, intelectuais,

1 - Disponivel em: http://dgp.cnpq.br/dgp/espelhogrupo/0123760573081386. Acesso em: 22 out. 2018. 
físicas e emocionais. Grandes exposições exigem condições de mobilidade, tempo e ritmo. A Bienal de São Paulo, em especial, por sua localização no Parque Ibirapuera, é também um convite ao contato com um dos espaços de lazer mais visitados da cidade. 0 Pavilhão da Bienal, edifício projetado por Oscar Niemeyer, tem dimensões monumentais: $250 \times 50$ metros, distribuidos em três andares. Sua imagem exterior, um volume em forma de paralelepípedo com brises verticais de alumínio na fachada principal, não revela as curvas sinuosas que residem em seu espaço interior. Ao adentrarmos na Bienal, nosso corpo já passou pela experiência do trânsito ao redor do parque, carros, bicicletas, skates, vendedores ambulantes, famílias caminhando com carrinhos de bebês, pessoas com seus cachorros e fones de ouvido, filas... $\mathrm{Na}$ sua $33^{a}$ versão, a Bienal abriga duas entradas pelo térreo. A passagem é vivida em vários momentos e situações: seguranças, monitores, grupos ruidosos, crianças com uniformes escolares e muitas pessoas olhando para seus telefones celulares ou tirando selfies no ambiente.

\section{ANTONIO BALLESTER MORENO}

Logo na entrada, no térreo, somos recebidos por uma espécie de instalação-paisagem formada por vários elementos. Um conjunto de aproximadamente seis mil cogumelos de argila dialoga com grandes painéis de pinturas que apresentam imagens da natureza. Projeto de Antonio Ballester Moreno, artista e curador espanhol, que, em sua poética, aborda temas diversos, como educação, aprendizagem, ecologia e projetos baseados em processos.

As pinturas são, ao mesmo tempo, grandes, imponentes e simples, realizadas intencionalmente em um estilo primitivo, com cores primárias chapadas e formas repetidas. Essa intenção reflete o interesse de Moreno de problematizar as separações entre alta cultura e cultura popular. Os cogumelos, por sua vez, dispostos no chão em círculo, com cores, formas e tamanhos variados, foram realizados com a colaboração de mais de 600 crianças do Centro Educacional Unificado (CEU)2 Pera Marmelo de São Paulo. É importante lembrar que o artista já adotara essa prática de convidar crianças para participar de suas obras em outros momentos, como em iVivan los campos libres de España! ${ }^{3}$, mostra realizada em 2017, em Madri.

Um primeiro olhar para esse conjunto de trabalhos já nos revela o quanto a paisagem externa ao pavilhão dialoga com o espaço interno e suas obras. Pensado como projeto sistêmico, o projeto de Moreno nos leva a perceber pontes, amarrações entre os elementos. Em seu discurso, o artista enfatiza a importância de se pensar a natureza como um todo, onde nenhum elemento encontra-se dissociado. Da mesma forma, essa obra nos convida a buscar

2 - Os Centros Educacionais Unificados são projetos educacionais criados pela Secretaria Municipal de Educação de São Paulo e localizados nas áreas periféricas da Grande São Paulo.

3 - Mais informações sobre essa exposição estão disponiveis em: https://bit.ly/2zJ3jXF. Acesso em: 12 dez. 2019. 
pontos de união, espelhamento e diálogo. Moreno, em entrevista gravada em vídeo, relata-nos que sua intenção foi criar um ambiente amável, reconfortante. Para ele, o essencial é buscar o sentido comum - aquele que todos compartilham.

Em consonância com a proposta do curador-geral, Gabriel Pérez-Barreiro, começamos a nos ambientar na mostra e a perceber o quanto a atenção aos detalhes, às sensações que nosso corpo nos desperta será fundamental para usufruir a visita. Atenção. 0 interesse pelo tema da atenção aparece também no texto de Pérez-Barreiro presente na publicação do projeto educativo. Para ele, a atenção é a base da prática curatorial:

\begin{abstract}
A relação entre as artes visuais e a atenção parece evidente: a arte existe para ser percebida e, para isso, é necessário prestar atenção. No entanto, se observarmos como a maioria das pessoas se movimentam em museus e em exposições, normalmente constatamos o contrário, ou seja, os visitantes vão de um objeto ao outro, sem se deter por mais do que alguns segundos em cada um deles, antes de seguir adiante (PÉREZ-BARREIRO, 2018).
\end{abstract}

Sem atenção não podemos perceber nosso corpo, vibrações e afetos. Sem atenção, nossa experiência do cotidiano se torna cada vez mais mecânica, dispersa. Não por acaso a cultura das multitarefas é também uma cultura de depressão, esgotamento e vazio. De uma vida sem atenção só podemos extrair arrependimentos, frustração e dores. É da atenção que deriva a construção de sentido, a realização e qualquer possível expansão da consciência. Um pequeno conto zen nos revela o pensamento oriental; um aluno pergunta ao seu mestre: - o que devo fazer para alcançar a iluminação? 0 mestre, de forma calma e pausada, responde: - preste atenção. 0 jovem discipulo espera um pouco e repete a pergunta: - Mestre, o que devo fazer para alcançar a iluminação? Uma vez mais, o mestre, de forma calma e pausada, responde: - preste atenção.

A lição não poderia ser mais clara. Não precisamos fazer nada, apenas o mais difícil. Parar, concentrar, prestar atenção na vida, em seus gestos mais corriqueiros, seus ritmos, movimentos. Shusterman (2008, p. 6), citando Montaigne, associa a ampliação das capacidades perceptivas à capacidade de prazer, encantamento e satisfação: "eu aprecio (a vida) duas vezes mais do que os outros, porque a medida do apreço depende da maior ou menor atenção que the concedemos".

\title{
MARK DION
}

Voltando ao espaço da Bienal, caminhando mais um pouco, ainda no térreo, escolhemos nos deter na observação de uma instalação que lembra um ambiente de um museu natural. Composta por biombos, objetos organizados em vitrines e mesas, utensílios de pintura, 
cadeiras e luminárias, a instalação provoca estranhamento. Nos biombos, pequenos desenhos e aquarelas representam flores, folhas, pedaços de troncos, insetos entre outros objetos, como latas de cervejas e caixas Tetra Pak.

Com uma proposta de trabalho que interconecta arte e ciência e abrange livros de artista e instalações realizadas a partir de pesquisas no acervo de instituições, o artista Mark Dion, em sua prática, adota uma sequência de "coletar, selecionar, classificar e exibir" (PUTNAM, 2002, p. 40), procedimentos que o aproximam de práticas científicas como a arqueologia, botânica, zoologia e paleontologia. Para a 33a Bienal de São Paulo, convidado para o projeto curatorial de Moreno, Dion escolheu o Parque Ibirapuera como ponto de partida para seu trabalho de site-specific processual ${ }^{4}$.

No projeto Estação Campo: Parque Ibirapuera, Dion convidou os artistas Bruno Novaes, Bryan M. Wilson, Dana Sherwood, Giba Gomes, Marlene Stamm, Nina Nichols e Vania Coelho para participar das expedições diárias no Parque. Os convidados buscam, coletam, selecionam e retratam os materiais encontrados. A proposta de Dion dá continuidade a outros trabalhos realizados em parques e espaços públicos como museus e universidades de várias partes do mundo. Entre seus projetos, destacam-se: Neukom Vivarium, uma instalação multimídia de 2006, realizada no Olympic Sculpture Park de Seattle, em Washington, nos Estados Unidos; Den, uma instalação site-specific para o National Tourist Routes na Noruega (2012); a instalação An archaeology of knowledge para o Johns Hopkins University (2012), e a publicação do livro High line: a field guide and handbook, de 2017.

Ao propor um sistema de arquivo e catalogação de objetos encontrados no Ibirapuera (naturais e culturais), Dion nos provoca sentimentos complexos. Prestando atenção às imagens dos biombos, empreendemos uma jornada imaginativa e nos situamos em um passeio pelo parque. Nesse passeio, podemos nos encantar com a beleza das cores de uma aquarela da flor ave-do-paraiso (de nome científico Strelitzia reginae) ou de uma borboleta e admirar a delicadeza do desenho que retrata um inseto, e, logo em seguida, depararmo-nos com a imagem de um objeto qualquer, algo descartado e que, pelo descaso, povoa o mesmo ambiente. Provocativa, a Estação Campo de Dion, ao apresentar um acervo de imagens dos objetos encontrados, estimula-nos a caminhar pelo parque com os sentidos abertos à descoberta.

\section{MARIA LAET}

A carioca Maria Laet é uma dentre os doze artistas que apresentam projetos individuais na $33^{a}$ Bienal de São Paulo. Sua proposta é composta por dois trabalhos, Abismos das super-

4 - Escolhemos não traduzir a expressão. Uma tradução livre poderia ser: "projeto processual para locais especificos". 
fícies / e II, dois vídeos de 2' e 3'44", respectivamente, projetados em sequência dentro de uma sala construida para essa finalidade. Cada video capta um detalhe do chão dentro do espaço do prédio da Bienal. A imagem projetada remete a uma ideia de quadro, sem cortes e/ou movimentos de câmera e apresenta como elementos animados as imagens refletidas no concreto, colocando em destaque a luz incidente sobre o ambiente.

Os reflexos capturados nos vídeos são resultado de uma relação entre a luz solar incidente no ambiente e os elementos que se colocam entre esta e o chão, sejam eles as estruturas arquitetônicas que compõem o Pavilhão da Bienal, seja o entorno, nos componentes da natureza do Parque lbirapuera dispostos nas proximidades, como o movimento das árvores. Essa relação é fundamentada no contraste entre o movimento orgânico criado pelos recursos naturais em oposição à estética das estruturas construídas, sempre rígidas. 0 piso do edificio, que aparece como suporte para esses reflexos, é também utilizado para expor marcas das ações do tempo em seus detalhes, sinalizando a utilização do espaço e as ações da natureza sobre o concreto, que resultaram em rachaduras e outras marcas de desgaste.

A artista afirma apreciar as coisas que usualmente não são notadas, que desaparecem perante um mundo que costuma chamar mais atenção:

\footnotetext{
Quando eu vim ao Pavilhão da Bienal, me impressionou o vazio imenso criado pela arquitetura que se impõe, tão forte. E justamente por ser tudo tão grande e importante, minha atenção se voltou ainda mais para as sutilezas desse espaço vazio, o que há de mais frágil e silencioso naquele contexto, o que não está sendo visto. 0 contraste entre esses mundos, e onde eles se encontram, é muito potente para mim (LAET, 2018).
}

0 tempo dos vídeos, que duram poucos minutos, em conjunto com o áudio capturado do ambiente do Pavilhão, expande-se na sala de projeção ganhando uma dimensão muito maior do que costumamos ter no dia a dia. Essa paisagem evidencia o cotidiano que, nos pequenos detalhes, carrega pistas da constante transformação do espaço. Nesse intuito, Laet propõe uma reflexão sobre as complexas relações entre a natureza e a ação do ser humano, perceptível em parques urbanos, sugerindo uma percepção mais sensitiva do espaço.

\section{SEBASTIÁN CASTAGNA}

A obra Ex situ, de Sebastián Castagna, artista argentino radicado em Londres, é uma instalação sonora situada em sala de estrutura circular no segundo andar do Pavilhão da Bienal que propõe um desafio para nossos sentidos. Antes de entrar na instalação, logo na entrada, os visitantes recebem instruções de uma pessoa responsável pela monitoria, que disponibiliza coletes refletivos de segurança. Um texto, afixado na entrada do local, informa: 
Esta sala é totalmente escura, mas não se preocupe: está vazia, então os visitantes não irão esbarrar em nada;

Há duas projeções muito tênues dentro da sala, e os olhos precisam se acostumar à pouca intensidade de luz para poderem enxergar;

Idealmente, fique no mínimo 2 minutos dentro para que os olhos e ouvidos se adaptem às condições do espaço;

Não acenda a lanterna do celular e não converse (o silêncio é necessário).

As primeiras sensações que nos invadem falam de suspensão do tempo e recolhimento. Sabendo que o silêncio é necessário para a fruição da obra, preparamo-nos para vivenciar mudanças tanto de sonoridade como de luminosidade. Afinal, estamos saindo de um espaço iluminado e barulhento. Após receberem essas recomendações, os visitantes percorrem um pequeno corredor que leva ao espaço da instalação, separado por dois lances de cortinas na cor preta que barram completamente a entrada da luz exterior. 0 espaço interno da instalação é pequeno, podendo ser percorrido em poucos passos. Os olhos demoram alguns minutos para se adaptarem e começarem a perceber a luz tênue de duas imagens em movimento dispostas pouco à frente do local de entrada, uma projetada em um suporte fixado mais ao alto da estrutura e outra logo abaixo, no chão do local. Mesmo depois de algum tempo, com a visão bem adaptada às condições, ainda é difícil determinar com exatidão os elementos que aparecem nas projeções, que nunca chegam a ficar completamente nítidas. Dedicando um pouco mais tempo à apreensão do trabalho, nossa percepção é novamente transformada. Agora começamos a reconhecer algumas formas, como imagens capturadas em tempo real do Pavilhão da Bienal e de seu entorno, como a rampa do edifício e a movimentação de árvores situadas ao lado, no Parque Ibirapuera.

A sonoridade da sala, distribuída em dez canais de áudio, desenvolve a percepção de que os sons são transmitidos a partir de pontos situados nas diversas direções do ambiente. As paisagens sonoras utilizadas para construir esse espaço são compostas por arquivos de sons gravados dentro e fora do Pavilhão da Bienal, posteriormente isolados das gravações e rearranjados para criar as paisagens sonoras fictícias, resultando na edição de uma trilha marcada por contínua transformação, na qual podemos distinguir vozes, ruídos da natureza, baruIhos urbanos e melodias que ora podem ser discriminados com maior clareza, ora se mesclam na edição; a principal faixa é composta a partir da gravação de campo com a ave noturna mãe-da-lua. Característica marcante de tais paisagens sonoras é o fator de uma alternância de sua intensidade que não permanece estável ao decorrer da trilha, pelo contrário, explora as variações entre elevações extremas do volume e os silêncios.

Além das instruções iniciais recebidas, os visitantes não são submetidos a nenhuma outra orientação e podem permanecer no espaço o tempo que julgarem necessário e se locomoverem conforme as próprias motivações. 
Ex situ faz parte do projeto da curadoria 0 pássaro lento, da artista argentina Claudia Fontes. Segundo sua proposta, a curadora tem por objetivo oferecer ao visitante uma relação mais aprofundada referente ao tempo e ao espaço, indo contra a corrente do fetiche atual de velocidade. 0 fio condutor para o desenvolvimento das obras dos artistas convidados é a imagem do pássaro lento, como metáfora para os diferentes tipos de vida, humana ou não, que se encontram no espaço do Pavilhão da Bienal e no parque ao redor, em suas diferentes temporalidades e percepção do espaço. Para Fontes (2018), "o pássaro lento não funciona em nossa exposição como um tema ou ideia a ilustrar, e sim como uma figura ambígua oferecida como território comum a partir do qual os artistas convidados iniciaram processos criativos únicos e diversos entre si".

Escolhendo manter espaços vazios, a proposta também dialoga com o conto policial "0 mistério de quarto fechado", texto encomendado a Pablo Martín Ruiz, com base no qual, segundo a curadora: "[...] se desvelam aspectos do voo curatorial do pássaro lento: considerar o espectador como leitor, o curador como tradutor, o fato artístico como evidência de um enigma, e a certeza de que esse enigma tem tantas possibilidades de resolução quanto leitores" (FONTES, 2018).

A instalação de Castagna e algumas outras obras presentes na $33^{a}$ edição da Bienal vão ao encontro às questões abordadas por Lorenzo Mammi (2012, p. 98-100) a respeito da necessidade de diálogo entre a obra e o local no qual ela é exibida, levando em consideração o questionamento de autonomia objetiva da obra; consequentemente, a indispensabilidade de um local neutro, que não interfira na criação e leitura dessa arte, é substituída pela urgência em afirmar a influência que o espaço em pauta passa a exercer sobre a obra de maneira indissociável. Nesse caso, o fator presencial da sala escura, situada dentro do Pavilhão da Bienal, é de fundamental importância para que promova essa relação direta e clara entre o universo proposto e os elementos e cotidianos do local que o cercam.

0 som coletado da ave popularmente conhecida como mãe-da-lua, com nome científico de Nyctibius griseus, foi utilizado na faixa principal da instalação, estabelecendo uma importante relação com a proposta da obra. A ave, conhecida também por nomes indigenas da região de Mato Grosso, como urutau, urutau-comum, urutágua, urutago, Kúa-kúa e Uruvati, e no Peru como Ayaymama, possui hábitos noturnos, alimenta-se na noite e apresenta uma capacidade de adaptação visual chamada olho mágico. Fisiologicamente, essa ave tem duas fendas na pálpebra superior, o que permite que ela consiga observar os arredores com os olhos fechados.

$\mathrm{Na}$ instalação, o artista, a partir das duas projeções realizadas com pouca incidência de luz, propõe a vivência de uma experiência próxima da mãe-da-lua, em que o visitante observa o ambiente exterior mesmo imóvel e quase sem luz, adaptando-se a essas condições. 
Ainda que a obra proponha o distanciamento do real para que haja um mergulho nessa atmosfera, a qualidade da percepção é estimulada a partir da utilização de imagens que remetem à observação dos elementos do mundo que está ao redor. Não por acaso, Castagna, ao trazer imagens que pertencem à própria experiência de visitar a Bienal, propõe um despertar da atenção sobre o corriqueiro, sobre o que passa, produzindo ressignificações simbólicas quanto ao significado de corpos comuns. Assim, os corpos dos visitantes são midiatizados, traduzidos em sombras que se movem em um ambiente sonoro e poético.

A experiência da instalação remete também a certas narrativas fantásticas que exploram a modificação do comportamento humano em relação ao mundo a partir da transfiguração de algum de seus sentidos. Uma relação com o imaginário da cultura pode ser proposta a partir do romance Ensaio sobre a cegueira, de José Saramago (1995). No livro, o autor sugere a situação inusitada de uma sociedade que é devastada por uma epidemia de cegueira branca. 0 contexto faz com que as pessoas entrem em desespero e deixem de lado as convenções da vida urbana em comunidade para se voltarem a uma conduta instintiva, marcada por violência, ganância e barbárie, que, em algumas situações, contrastam com atitudes de compaixão, apoio e proteção. A perda abrupta do sentido da visão mostra que, por mais que as adaptações sejam possíveis e necessárias, o ser humano não está preparado ou disposto a lidar de maneira constante com essas modificações em seu dia a dia.

Outra referência a que a instalação de Castagna nos remete é o romance Blecaute, de Marcelo Rubens Paiva (1986). Na história, três universitários ficam presos por três dias no interior de uma gruta e, ao saírem, se deparam com a cidade de São Paulo paralisada, pessoas transformadas em estátuas por algum fenômeno inexplicável. Muito mais do que apontar para causas e respostas a respeito do ocorrido, o autor se dedica a explorar o comportamento dos três sobreviventes em relação a um mundo que, apesar de aparentemente manter toda sua estrutura, já não é mais o mesmo. Nesse mundo, os protagonistas vivem experiências insólitas e, por meio de suas reflexões sobre o que vivenciam, conseguem produzir as mudanças necessárias para essa situação.

Levando em consideração a proposta da obra que explora limites e distorções visuais e auditivas dentro de um ambiente isolado a partir de matéria-prima encontrada em seus arredores, é possível pensar uma terceira associação. Talvez mais direta, mas nem por isso menos profunda, a instalação Ex situ também revisita temas abordados na "Alegoria da caverna" de Platão (2001). Na conhecida passagem, o filósofo explana a situação de três homens que, fadados a viverem acorrentados em única posição dentro de uma caverna, conseguem ver apenas sombras projetadas na superficie à sua frente. As sombras são criadas por objetos carregados entre uma fogueira e um muro atrás dos prisioneiros.

Na instalação, as condições de pouca luz, dificultando a nitidez das imagens, e as edições de som promovem um paralelo direto com a situação descrita por Platão. No entanto, o que Castagna estabelece em sua instalação é justamente o processo contrário, visto que o visi- 
tante é levado a adentrar na caverna e, com esse gesto, produzir uma situação que exige transformações nos órgãos da percepção. No processo de adaptação de um ambiente exterior, em que há uma luminosidade com a qual estamos habituados a conviver em nosso cotidiano, para a condição de uma quase ausência de claridade que predomina na sala, 0 visitante começa a perceber uma sonoridade difusa que emerge do silêncio, o movimento das sombras e a lenta revelação das imagens.

Assim, na contramão da alegoria platônica que aponta para a valorização da luz, da razão e do acesso ao mundo inteligivel, a obra de Castagna nos leva a perceber o valor do ambiente fechado, as qualidades de uma percepção concentrada, do sombrio e do silêncio. É nesse contexto invertido que Castagna nos leva a perceber o que nos escapa e a rever as necessidades do nosso corpo que, tão frequentemente sobrecarregado por estímulos diversos, clama por recolhimento.

\section{CONCLUSÕES: VIVENDO A SOMAESTÉTICA NA BIENAL}

Nosso artigo teve como objetivo discutir as relações entre processos de criação em curadoria, experiência estética e percepção do corpo. Na criação da cartografia somaestética acerca da 33a Bienal de São Paulo, o projeto curatorial de Pérez-Barreiro forneceu as pistas conceituais. Seguindo a intenção de vivenciar as visitas como experiências transformadoras, fundadas na ideia de afinidades afetivas, na observação do tempo e na atenção concentrada, escolhemos quatro trabalhos. Por meio de um entendimento de curadoria como um amálgama de espaços de liberdade, vazios, afinidades e escolhas afetivas, nosso estudo teceu reflexões sobre somaestética e as proposições das obras. No processo cartográfico, priorizamos trabalhar em três camadas que se comunicam: 1. qualidades da obra e estímulos de percepção; 2. entendimentos sobre o corpo, os corpos dos visitantes, os corpos das obras e os corpos do ambiente ao redor do pavilhão; 3 . relações com o imaginário da cultura, planos de interpretação e busca de sentido. Em harmonia com a proposta de Pérez-Barreiro, nossa cartografia se fundou, em especial, como um exercicio de atenção.

A falta de tempo, o excesso de atividades, as cobranças e os estímulos fazem de nossa época uma cultura do cansaço (HAN, 2017). A arte como agenciadora de experiências estéticas é capaz de mobilizar processos de sensibilizações que, por sua vez, encaminham mudanças de comportamento e finalmente são capazes de gerar transformações lógicas, isto é, mudanças no entendimento, na consciência e na forma de ver o mundo. Nesse sentido, a proposta do crítico de arte Mário Pedrosa de enfatizar as ligações entre arte e política e o pensamento goethiano sobre a emergência de atrações e afinidades puderam nos dar pistas para olharmos para a Bienal como um espaço vivenciado. Assim, a Bienal se transforma em dispositivo capaz de agenciar transformações e problematizar as relações automáti- 
cas e dispersas que temos com o próprio corpo, com o corpo dos outros visitantes, com o corpo das obras e com o corpo do espaço/paisagem/natureza ao redor do pavilhão do lbirapuera. Como recorte escolhido, trouxemos para o diálogo o pensamento de Shusterman, em especial sua proposta de somaestética como um estudo crítico sobre como vivenciamos o corpo vivo. Para a discussão, argumentamos a respeito da importância do cultivo das qualidades perceptivas.

Na obra de Ballester Moreno, o despertar de um tipo ampliado de consciência do corpo foi acionado a partir de um entendimento sistêmico e, por que não dizer, ecológico, que emanou de um diálogo com sua "instalação-paisagem". Nas relações entre corpos, imagens, pinturas, cerâmicas, formas, cores e texturas e o próprio espaço expositivo, uma percepção de complexidade se descortinou e todo o parque ao redor comungou da experiência somaestética vivenciada.

Com Mark Dion, pudemos empreender jornadas imaginadas e imaginárias por um parque a descobrir. Com seus processos de expedição, coleta, seleção e registro, os objetos achados no percurso se transformam em imagens-arquivos de um museu, ao mesmo tempo, natural e cultural. Nosso corpo, ao visitar a instalação, vivencia experiências paradoxais e complexas. Do encantamento da flora às maravilhas da fauna, Dion não exclui de nosso percurso o assombro dos objetos que documentam os excessos do consumo e que são displicentemente descartados. Nessa obra, as relações entre o dentro e o fora da exposição se fazem presentes em traduções e denúncias. Colocados lado a lado de exemplos naturais, registros da desatenção e do descaso configuram uma percepção alterada do ambiente e de suas relações com a cultura.

A necessidade de cultivar uma sensibilidade somaestética capaz de promover uma consciência expandida e equilibrar a sobrecarga de estímulos que vivemos aparece de forma enfática no projeto poético de Maria Laet. A artista, em seu processo de criação, fala-nos sobre o seu encanto pelas sutilezas dos vazios, por devaneios que perambulam sem metas predefinidas e pelos silêncios que se escondem nos espaços entre as coisas. Com Laet, viajamos para fronteiras movediças que passam despercebidas e nos impulsionam a novas ousadias e encontros. A partir dessas vivências, leves como brisas, somos capazes de compreender a potência que reside na suavidade.

Suspensão e recolhimento são sentimentos que nos acompanharam na experiência de Ex situ, de Sebastián Castagna. Como que um refúgio em meio aos inúmeros estímulos da Bienal, a instalação parece de fato "fora do lugar". No entanto, por sua capacidade de despertar intensidades adormecidas, ultrapassar limites e ampliar a consciência das capacidades perceptivas do corpo, Ex situ é um dispositivo de somaestética.

Assim, nosso estudo nos revelou que a $33^{\text {a }}$ Bienal, em sua ecologia vibrante e tensa, convida-nos a prestar atenção nos fenômenos e, no encontro com as teias de afinidades e afetos, cultivar a somaestética vivenciando nossos corpos em percepções transformadas. 


\title{
Curating, body and perception at the 33rd Bienal de São Paulo: a somaesthetics cartography
}

\begin{abstract}
This article explores the relationship between curatorial creation processes, aesthetic experiences and the body perception. Curatorial creation processes of big art exhibitions such as the Bienal de São Paulo and Documenta of Kassel, aim to stimulate transformative aesthetic experiences in various senses. In this context, our objective is to discuss how the curating project of the 33rd Bienal de São Paulo (2008), with general coordination by Gabriel Pérez-Barreiro, problematizes the perception of the body, both in the relation of the visitor with his individual body, and in network with the body of the works and the exhibition space. Our argument is that, in his curating process, Pérez-Barreiro, launches an experience that potentiates different levels of physical consciousness. The article proposes reflections about the concept of somaesthetics (Shusterman) and adopts the cartography as method (Leão).
\end{abstract}

Keywords: Curatorial processes. Bienal de São Paulo. Aesthetic experience. Body perception. Cartography.

\section{REFERÊNCIAS}

DALCOL, F. Mário Pedrosa e a revolução afetiva da forma. Arte \&t Crítica/Jornal da abca, ano XV, n. 42, jun. 2017. Disponivel em: https://bit.ly/2quxqKP. Acesso em: 30 out. 2018.

DELEUZE, G.; GUATTARI, F. Mil platôs: capitalismo e esquizofrenia. Rio de Janeiro: Editora 34, 1995. v. 1.

DEWEY, J. Art as experience. Carbondale: Southern Illinois University Press, 1987.

DION, M. The High Line: a field guide and handbook: a project by Mark Dion. New York: Printed Matter, 2017.

FONTES, C. Exposições coletivas: O pássaro lento. Fundação Bienal de São Paulo, 2018. Disponivel em: https://bit.ly/2DoHr4z. Acesso em: 30 out. 2018.

GOETHE, J. W. von. As afinidades eletivas. Tradução de Conceição G. Sotto Maior. Rio de Janeiro: Ediouro, 1992.

HAN, B.-C. Psychopolitics: neoliberalism and new technologies of power. New York: Verso, 2017.

LAET, M. Depoimento. Fundação Bienal de São Paulo, 2018. Disponivel em: www.bienal.org. br/texto/5232. Acesso em: 30 out. 2018.

LEÃO, L. The mirror labyrinth: reflections on bodies and consciousness at cybertimes. Technoetic Arts, Bristol, v. 3, n.1, p. 19-41, 2005.

LEÃO, L. Corpo, performance e redes. Revista Polêmica, v. 16, p. 16-44, 2006. 
LEÃO, L. Corposcopio: an interactive installation performance in the intersection of ritual, dance and new technologies. Technoetic Arts, Bristol, v. 5, p. 113-117, 2007.

LEÃO, L. Paradigmas dos processos de criação em mídias digitais: uma cartografia. V!RUS, v. 6, p.5-27,2011.Disponivelem:http://www.nomads.usp.br/virus/virus06/?sec=3\&titem=1\&lang=pt. Acesso em: 22 out. 2018.

MAMMi, L. O que resta: arte e crítica de arte. São Paulo: Companhia das Letras, 2012.

MATURANA, H. R.; VARELA, F. J. Autopoiesis and cognition: the realization of the living. Boston: Springer, 1991.

OBRIST, H. U. Caminhos da curadoria. Rio de Janeiro: Cobogó, 2014.

O'NEILL, P. The culture of curating and the curating of culture(s). Cambridge, MA: MIT Press, 2012.

PAIVA, M. R. Blecaute. São Paulo: Brasiliense, 1986.

PEDROSA, M. Forma e percepção estética. São Paulo: Edusp, 1995.

PÉREZ-BARREIRO, G. Afinidades afetivas. Texto curatorial. Fundação Bienal de São Paulo, 2018. Disponivel em: https://bit.ly/2ANolTf. Acesso em: 30 out. 2018.

PLATÃO. A República. Lisboa: Fundação Calouste Gulbenkian, 2001.

PUTNAM, J. Le musée à l'oeuvre: le musée comme médium dans l'art contemporain. Paris: Thames \& Hudson, 2002.

SALLES, C. A. Arquivos de criação: arte e curadoria. Vinhedo: Horizonte, 2010.

SARAMAG0, J. Ensaio sobre a cegueira. São Paulo: Companhia das Letras, 1995.

SHUSTERMAN, R. Pragmatist aesthetics: living beauty, rethinking art. Oxford: Blackwell, 1992.

SHUSTERMAN, R. Body consciousness: a philosophy of mindfulness and somaesthetics. Cambridge: Cambridge University Press, 2008.

SMITH, T. Thinking contemporary curating. New York: Independent Curators International, 2012. 